\title{
Phytoprotection
}

\section{Fungal communities isolated from dead apple leaves from orchards in Quebec}

\section{J. Bernier, O. Carisse et T.C. Paulitz}

Volume 77, numéro 3, 1996

URI : https://id.erudit.org/iderudit/706109ar

DOI : https://doi.org/10.7202/706109ar

Aller au sommaire du numéro

Éditeur(s)

Société de protection des plantes du Québec (SPPQ)l

ISSN

0031-9511 (imprimé)

1710-1603 (numérique)

Découvrir la revue

Citer ce document

Bernier, J., Carisse, O. \& Paulitz, T. (1996). Fungal communities isolated from dead apple leaves from orchards in Quebec. Phytoprotection, 77(3), 129-134. https://doi.org/10.7202/706109ar
Résumé de l'article

Le champignon causant la tavelure du pommier, Venturia inaequalis, hiverne dans les feuilles mortes de pommier (Malus pumila) sous forme de pseudothèces. Les objectifs de cette étude étaient de monter une collection de champignons afin de vérifier subséquemment leur résistance au froid et leur potentiel antagoniste contre $V$. inaequalis et d'acquérir des connaissances sur la microflore des feuilles mortes de pommiers. Des champignons ont été isolés sur des feuilles mortes de pommiers récoltées au printemps et à l'automne de 1993. Au total, 345 isolats fongiques provenant de 49 genres ont été identifiés. Quinze genres sont rapportés pour la première fois comme colonisateurs des feuilles de pommiers en Amérique du Nord. 


\title{
Communication brève / Short Communication \\ Fungal communities isolated from dead apple leaves from orchards in Quebec
}

\author{
Julie Bernier ${ }^{1}$, Odile Carisse ${ }^{2}$, and Timothy C. Paulitz ${ }^{1}$
}

Received 1996-04-30; accepted 1996-12-28

\begin{abstract}
Venturia inaequalis, the causal agent of apple scab, overwinters in apple (Malus pumila) leaves on the orchard floor by producing pseudothecia. The objectives of this survey were to make a collection of fungi to be subsequently tested for their potential as psychrophile biocontrol agents against $V$. inaequalis and to acquire knowledge on the diversity of the microflora of dead apple leaves. Fungi were recovered from dead apple leaves collected in the spring and fall of 1993. A total of 345 isolates from 49 genera were identified. Fifteen genera were not previously recorded as colonizers of apple leaves in North America.
\end{abstract}

Bernier, J., O. Carisse et T. C. Paulitz 1996. Communauté fongique isolée des feuilles mortes de pommiers dans des vergers du Québec. PHYTOPROTECTION 77 : 129-134.

Le champignon causant la tavelure du pommier, Venturia inaequalis, hiverne dans les feuilles mortes de pommier (Malus pumila) sous forme de pseudothèces. Les objectifs de cette étude étaient de monter une collection de champignons afin de vérifier subséquemment leur résistance au froid et leur potentiel antagoniste contre $V$. inaequalis et d'acquérir des connaissances sur la microflore des feuilles mortes de pommiers. Des champignons ont été isolés sur des feuilles mortes de pommiers récoltées au printemps et à l'automne de 1993. Au total, 345 isolats fongiques provenant de 49 genres ont été identifiés. Quinze genres sont rapportés pour la première fois comme colonisateurs des feuilles de pommiers en Amérique du Nord.

In Quebec, apple scab caused by the fungus Venturia inaequalis (Cke.) Wint., is the most important disease in apple (Malus pumila Mill.) production. Effective control of apple scab requires from 6 to 16 fungicide applications every season (Jones and Aldwinckle 1990). On top of the environmental problems that result from fungicide applications, the patho- gen is becoming increasingly resistant to fungicides, particularly to benomyl [methyl-N-(1-butylcarbamoyl)-2-benzimidazole carbamate], dodine [n-dodecyl guanidine acetate] and fenarimol [2,4'-dichlorophenyl-alpha-pyrimidin-5-pirimidinemethanol] (Carisse and Pelletier 1994; Jones 1981). Therefore, there is an increasing interest in alternative ways to

1. Macdonald Campus of McGill University, 21111 Lakeshore Road, Sainte-Anne-de-Bellevue, Quebec, Canada H9X 3V9

2. Agriculture and Agri-Food Canada, 430 Gouin Blvd., Saint-Jean-sur-Richelieu, Quebec, Canada J3B 3E6. Author to whom correspondence should be addressed 
control this disease including biological control.

Because $V$. inaequalis grows as a saprophyte when it overwinters in the apple leaf litter, researchers have looked for possible organisms colonizing dead apple leaves. Cinq-Mars (1949) and Ross (1953) recovered apple leaf microflora to find potential natural antagonists of $V$. inaequalis. This approach was also pursued by Andrews and Kenerley (1979), Andrews et al. (1983), Heye (1982) and Simard et al. (1957). From all these studies, one interesting potential antagonist, Athelia bombacina (Heye 1982), was found in Wisconsin but has never been commercialized. Since the work of Andrews and Kenerley (1979), Andrews et al. (1983) and Heye (1982), this strategy has not been pursued. In addition, no work has focused on organisms adapted to the cold climatic conditions of eastern Canada. Rather than testing biocontrol agents developed in warmer climates, we proposed to search for indigenous organisms in Quebec.

We hypothesized that potential antagonists are present on apple leaves and that sampling of several orchards should provide a large diversity of microbial genera and increase the chance of finding potential biocontrol agents. Knowledge of the diversity of apple leaf microflora would contribute to develop a biological control agent against apple scab, particularly for orchard testing and for studies on fitness and adaptability of the biocontrol agent.

The objectives of this survey were to make a collection of fungi to be subsequently tested for their potential as biocontrol agents and to acquire knowledge on the diversity of the microflora of dead apple leaves.

The sampling was done in six apple (M. pumila cv. Mclntosh) orchards representing different apple growing regions in the province of Quebec, Canada. The orchards were situated at Covey Hill (lat. $45^{\circ} 01^{\prime} \mathrm{N}$, long. $73^{\circ} 48^{\prime} \mathrm{W}$ ), Deschambault (lat. 46 $39^{\prime} \mathrm{N}$, long. 71 ${ }^{\circ} 56^{\prime} \mathrm{W}$ ), Frelighsburg (lat. $45^{\circ} 03^{\prime} \mathrm{N}$, long. $72^{\circ} 50^{\prime} \mathrm{W}$ ), île $d^{\prime}$ Orléans (lat. $46^{\circ} 55^{\prime} \mathrm{N}$, long. $70^{\circ} 58^{\prime} \mathrm{W}$ ), Mont Saint-Hilaire (lat. $45^{\circ} 33^{\prime} \mathrm{N}$, long. $73^{\circ} 10^{\prime} \mathrm{W}$ ), and Saint-Joseph-du-Lac (lat. $45^{\circ} 32^{\prime} \mathrm{N}$, long. $74^{\circ} 00^{\prime} \mathrm{W}$ ). These orchards had been abandoned for more than $5 \mathrm{yr}$. It is very unlikely that fungicide treatment or residues could have affected the natural fungal microflora. Dead apple leaves lying on the ground were collected arbitrarily twice in 1993. The first collection was done in the spring after snow melt between 20 April and 23 April. The second collection was carried out just before the first snow fall in the fall, between 9 November and 15 November. The leaves were stored in paper bags and refrigerated at $4^{\circ} \mathrm{C}$ until processed (not more than 4 wk later).

Two isolation methods were employed to recover the largest number of organisms possible. In the first method, for each orchard, arbitrarily chosen leaves were placed in glass petri dishes of $9-\mathrm{cm}$ diam containing a Whatman filter paper saturated with distilled water to provide a moist environment. The petri dishes (four plates for each temperature level) were incubated at each of eight different temperatures $(-2,0,2,4,6,10,18$, and $24^{\circ} \mathrm{C}$ ), to favor growth of mesophilic and psychrophilic fungi, for 2-3 wk. The leaves were observed under a dissecting microscope and each mass of spores, fruiting bodies or mycelia was transferred to a half-strength V8 agar media (Dhingra and Sinclair 1985) amended with $100 \mu \mathrm{g} \mathrm{mL}^{-1}$ of chlorotetracycline and $200 \mu \mathrm{g} \mathrm{mL}^{-1}$ of streptomycin.

For the second method, $10 \mathrm{~g}$ of nonrinsed leaves were homogenized in a blender with $100 \mathrm{~mL}$ distilled water. The homogenates were diluted from $10^{-1}$ to $10^{-3}$ with four replicates per dilution. Aliquots of $0.5 \mathrm{~mL}$ of the suspensions were spread on V8 agar medium (half strength, with antibiotics as described above) and on potato agar made from an infusion of $200 \mathrm{~g}$ of unpeeled potatoes boiled for $0.5 \mathrm{~h}$. The latter medium (used to favor the basidiomycetes) was also amended with $15 \mu \mathrm{g} \mathrm{mL}^{-1}$ of benomyl (diluted in $95 \%$ alcohol). Antibiotics and the fungicide were added after autoclaving. In this method, there were four replicate plates for each medium for each dilution. There were 144 plates (6 orchards $\times 2$ media $\times 3$ dilutions $\times 4$ replicates) incubated at each of the eight temperature levels from -2 to $24^{\circ} \mathrm{C}$ for $3-4 \mathrm{wk}$. 
Colonies with different morphologies were transferred to V8 medium. Isolated fungi were identified according to the morphology of their structures (Barnett and Hunter 1987; Hanlin 1990).

From the spring collection, 189 different isolates were obtained and $71 \%$ of them were identified. They belonged to 38 different genera (Table 1). The most common genera were: Alternaria, Cladosporium, Coniothyrium, Penicillium, Phoma, Trichoderma and members of the order Mucorales. Aspergillus, Brachysporium, Curvularia, Geotrichum, Monilia, Mycogone, Tubercularia, and yeasts were isolated only from homogenized leaves. The genera Arthrobotrys, Cephalosporium, Chaetomium, Chaetophoma, Chalara, Diplodia, Hendersonia, Humicola, Hyalodendron, Paecilomyces, Pestalotia, Pyrenochaeta, Rhinotrichum, Rhizoctonia, Selenophoma, Sphaeropsis, Varicosporium and Verticillium were isolated only by the intact leaf method. From the autumn collection, 156 different isolates were obtained and $69 \%$ were identified, for a total of 26 genera (Table 1). Alternaria, Candida, Cladosporium, Coniothyrium, Epicoccum, Trichoderma, members of the Mucorales and yeasts were the most common. Bactrodesmium, Ceratosporella, Chaetomium, $\mathrm{Cy}$ lindrocarpon, Gilmaniella, Gliomastix, Monilia, Papularia, Phoma and various Mucorales were isolated only from diluted leaf homogenates. Melanconium, Sclerotinia, Trichoderma and Trichothecium were isolated only by the intact leaf method. When the two collections were compared (Table 1), 23 genera were found only in the spring, conversely 11 genera appeared only in the fall collection.

Because the leaves used for dilution plating were not surface sterilized, some of the organisms recovered may have come from the phylloplane, and may not be endophytes. Genera found only by the dilution plating method may not be common on or in the leaves, so they would be difficult to isolate from intact leaves because of competition from faster growing fungi. In fact, several fungi were isolated only once. On the other hand, it was demonstrated (Petrini 1991) that some epiphytes may, under appropriate conditions, colonize the interior of the host tissues. In the dead leaves used in the present study, it was assumed that there was no host specificity required for the endophytes to colonize the tissue due to the absence of host defenses present in living plants. Some epiphytic fungi may switch to an endophytic life style, first to decompose the leaf, and second to protect themselves against adverse conditions (snow cover) and also to reduce antagonistic activities by competitive microorganisms.

According to Bessey (1950) and Barnett and Hunter (1987), 18 of the 49 genera obtained are recorded as saprophytes, 25 as both saprophytes and parasites, and 6 as parasites only. More specifically, 11 of these potentially parasitic genera are recorded as apple tree pathogens in QSPP (1992) including Alternaria, Cladosporium, Coniothyrium, and Fusarium. Since many isolates were not identified to the species level, we do not know whether the specific isolates found in the orchards are pathogenic to apple.

The fungi were classified into three groups, depending on the range of temperatures at which they were isolated. Fungal genera isolated at cold temperatures $\left(-2\right.$ to $\left.10^{\circ} \mathrm{C}\right)$ were Aspergillus, Cylindrocarpon, Diplodia, Geotrichum, Hendersonia, Selenophoma, Sphaeropsis, Tubercularia, Varicosporium, and Verticillium. Genera of warm temperatures (18 and $24^{\circ} \mathrm{C}$ ) were Arthrobotrys, Brachysporium, Chaetophoma, Chalara, Curvularia, Gilmaniella, Gliomastix, Humicola, Hyalodendron, Melanconium, Monilia, Mycogone, Pestalotia, Rhinotrichum, Sclerotinia, and Trichothecium. The following genera, were isolated from cold as well as from warm temperatures and constitute the last group, Alternaria, Aureobasidium, Bactrodesmium, Botrytis, Candida, Cephalosporium, Ceratosporella, Chaetomium, Cladosporium, Coniothyrium, Epicoccum, Fusarium, Mortierella, order Mucorales, Paecilomyces, Papularia, Penicillium, Phoma, Pyrenochaeta, Rhizoctonia, Trichoderma, Ulocladium, and yeasts.

The fungi isolated solely at cold temperatures were infrequent, so we cannot determine per se whether more samples would have revealed their presence at 
Table 1. Number of isolates of $\mathbf{4 9}$ fungal genera recovered from dead apple ( $M$. pumila) leaves in Quebec orchards in spring and fall $1993^{\circ}$

\begin{tabular}{|c|c|c|c|c|}
\hline \multirow[b]{2}{*}{ Genera } & \multicolumn{2}{|c|}{ Spring } & \multicolumn{2}{|c|}{ Fall } \\
\hline & $\begin{array}{c}\text { Method } 1 \\
\text { (no. isolates) }\end{array}$ & $\begin{array}{c}\text { Method } 2 \\
\text { (no. isolates) }\end{array}$ & $\begin{array}{c}\text { Method } 1 \\
\text { (no. isolates) }\end{array}$ & $\begin{array}{c}\text { Method } 2 \\
\text { (no. isolates) }\end{array}$ \\
\hline Alternaria & 19 & 2 & 6 & 7 \\
\hline Arthrobotrys & 1 & - & - & - \\
\hline Aspergillus & - & 1 & - & - \\
\hline Aureobasidium & 3 & 1 & 2 & 4 \\
\hline Bactrodesmium & - & - & - & 2 \\
\hline Botrytis & 2 & 1 & - & - \\
\hline Brachysporium & - & 1 & - & - \\
\hline Candida & 5 & 2 & 1 & 10 \\
\hline Cephalosporium & 3 & - & - & - \\
\hline Ceratosporella & - & - & - & 6 \\
\hline Chaetomium & 1 & - & - & 1 \\
\hline Chaetophoma & 1 & - & - & - \\
\hline Chalara & 1 & - & - & - \\
\hline Cladosporium & 21 & 9 & 12 & 30 \\
\hline Coniothyrium & 12 & 2 & 1 & 14 \\
\hline Curvularia & - & 1 & - & - \\
\hline Cylindrocarpon & - & - & - & 1 \\
\hline Diplodia & 1 & - & - & - \\
\hline Epicoccum & 1 & 2 & 7 & 15 \\
\hline Fusarium & 6 & 5 & 4 & 4 \\
\hline Geotrichum & - & 2 & - & - \\
\hline Gilmaniella & - & - & - & 1 \\
\hline Gliomastix & - & - & - & 1 \\
\hline Hendersonia & 1 & - & - & - \\
\hline Humicola & 1 & - & - & - \\
\hline Hyalodendron & 1 & - & - & - \\
\hline Melanconium & - & - & 1 & - \\
\hline Monilia & - & 1 & - & 1 \\
\hline Mortierella & - & - & 2 & 1 \\
\hline Order Mucorales & 1 & 12 & - & 11 \\
\hline Mycogone & - & 3 & - & - \\
\hline Paecilomyces & 2 & - & - & - \\
\hline Papularia & - & - & - & 2 \\
\hline Penicillium & 14 & 3 & 1 & 8 \\
\hline Pestalotia & 1 & - & - & - \\
\hline Phoma & 10 & 1 & - & 8 \\
\hline Pyrenochaeta & 2 & - & - & - \\
\hline Rhinotrichum & 1 & - & - & - \\
\hline Rhizoctonia & 1 & - & 1 & 1 \\
\hline Sclerotinia & - & - & 1 & - \\
\hline Selenophoma & 1 & - & - & - \\
\hline Sphaeropsis & 1 & - & - & - \\
\hline Trichoderma & 11 & 9 & 10 & - \\
\hline Trichothecium & - & - & 1 & - \\
\hline Tubercularia & - & 1 & - & - \\
\hline Ulocladium & - & - & 1 & 1 \\
\hline Varicosporium & 1 & - & - & - \\
\hline Verticillium & 1 & - & - & - \\
\hline Yeasts & - & 5 & 1 & 14 \\
\hline
\end{tabular}

a Two isolation methods were employed : method 1 refers to isolation under binocular and method 2 refers to isolation from a leaf decoction plating. 
higher temperatures. The most common genera were isolated relatively equally over the whole temperature range. Further testing would be needed to determine whether the isolates are true psychrophiles. Nevertheless, using a range of isolation temperatures has increased the diversity of isolates.

It was also noticed that some genera were found only in specific orchards (Fig. 1). For example, in the spring collection, nine genera were found only in the Mont-Saint-Hilaire orchard. Sampling only one orchard would have resulted in a reduced number of genera recovered.

Our collection contained 24 new genera not previously reported from apple leaves. The genera Bactrodesmium, Brachysporium, Cephalosporium, Ceratosporella, Chaetophoma, Chalara, Curvu- laria, Cylindrocarpon, Gilmaniella, Hendersonia, Humicola, Melanconium, Monilia, Mortierella, Mycogone, Papularia, Pyrenochaeta, Rhinotrichum, Rhizoctonia, Selenophoma, Sphaeropsis, Tubercularia, Ulocladium, Varicosporium have not been isolated from green leaves or dead leaves by previous workers (Andrews and Kenerley 1978, 1979, 1980; Ross 1953; Simard et al. 1957).

Our collection also contains 9 genera that have not been reported on Malus spp.: Cephalosporium, Cylindrocarpon, Hendersonia, Monilia, Pyrenochaeta, Selenophoma, Sphaeropsis, Tubercularia, and Ulocladium (Farr et al. 1989; Jones and Aldwinckle 1990).

This survey clearly demonstrates the large diversity of fungal species living in or on dead apple leaves. These fungi

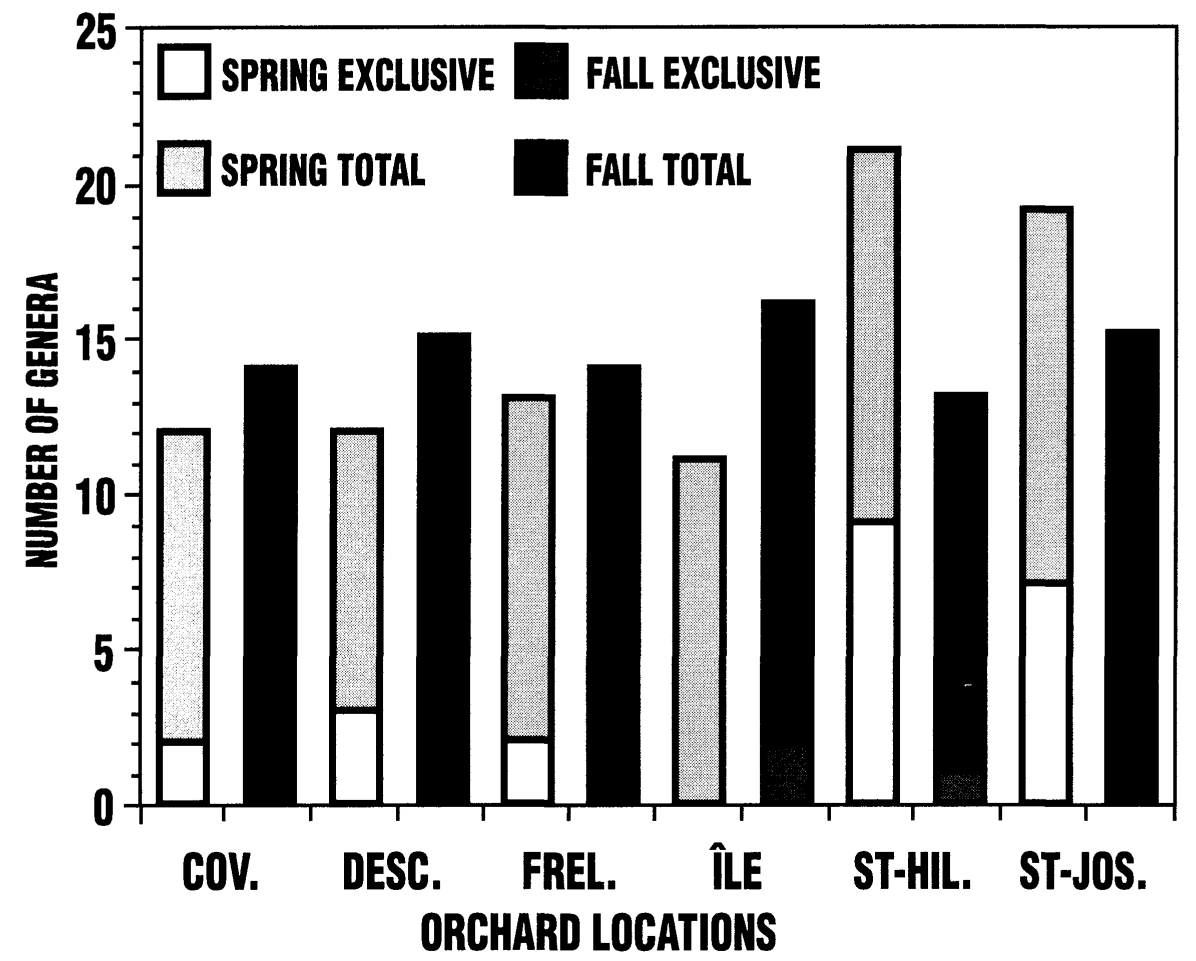

Figure 1. Number of genera isolated from dead apple leaves ( $M$. pumila) collected in orchards at each of six locations in Quebec in the spring and fall of 1993. Total : total number of genera isolated in a given orchard; exclusive : number of genera found exclusively in the given orchard; COV. : Covey Hill; DESC. : Deschambault; FREL. : Frelighsburg; îLE : île d'Orléans; ST-HIL. : Mont Saint-Hilaire; ST-JOS. : Saint-Joseph-du-Lac 
may be phylloplane inhabitants of living leaves, airborne colonizers of senescent leaves, or soil inhabitants. Several sampling sites were necessary to provide a large diversity of genera since the composition of the microbial community for each orchard was very different. The large diversity of fungal isolates recovered should increase the chances of finding antagonists that interfere with the overwintering of Venturia inaequalis. Sampling in several orchards, during two seasons and using two isolation methods probably helped in obtaining a high number of genera.

\section{ACKNOWLEDGEMENTS}

The authors wish to thank the Pest Management Alternatives Office for financial support.

\section{REFERENCES}

Andrews, J.H., and C.M. Kenerley. 1978. The effects of a pesticide program on non-target epiphytic microbial populations of apple leaves. Can. J. Microbiol. 24 : 10581072.

Andrews, J.H., and C.M. Kenerley. 1979. The effects of a pesticide program on microbial populations from apple leaf litter. Can. J. Microbiol. 25: 1331-1344.

Andrews, J.H., and C.M. Kenerley. 1980. Microbial populations associated with buds and young leaves of apple. Can. J. Bot. $58: 847-855$.

Andrews, J.H., F.M. Berbee, and E.V. Nordheim. 1983. Microbial antagonism to the imperfect stage of the apple scab pathogen, Venturia inaequalis. Phytopathology 73 : 228-324.

Barnett, H.L., and B.B. Hunter. 1987. Illustrated genera of imperfect fungi. $4^{\text {th }}$ ed. Macmillan Publ. Co., New York. 218 pp.

Bessey, E.A. 1950. Morphology and taxonomy of fungi. The Blakiston Co., Toronto. $791 \mathrm{pp}$.
Carisse, O., and J.R. Pelletier. 1994. Sensitivity distribution of Venturia inaequalis to fenarimol in Quebec apple orchards. Phytoprotection $75: 35-43$.

Cinq-Mars, L. 1949. Interactions between Venturia inaequalis (Cke) Wint. and saprophytic fungi and bacteria inhabiting apple leaves. M.Sc. Thesis. McGill University, Montreal, Canada. $114 \mathrm{pp}$

Dhingra, O.D., and J.B. Sinclair. 1985. Basic plant pathology methods. CRC Press, Boca Raton, Florida. 355 pp.

Farr, D.F., G.F. Bills, G.P. Chamuris, and A.Y. Rossman. 1989. Fungi on plants and plant products in the United States. APS Press, St. Paul, Minnesota. 1252 pp.

Hanlin, R.T. 1990. Illustrated genera of ascomycetes. APS Press, St.Paul, Minnesota. 263 pp.

Heye, C.C. 1982. Biological control of the perfect stage of the apple scab pathogen, Venturia inaequalis (Cke) Wint. Ph.D. Thesis, Univ. of Wisconsin, Madison. 99 pp.

Jones, A.L. 1981. Fungicide resistance: Past experience with benomyl and dodine and future concerns with sterol inhibitors. Plant Dis. 65 : 990-992.

Jones, A.L., and H.S. Aldwinckle. 1990. Compendium of apple and pear diseases. APS Press, St. Paul, Minnesota. 100 pp.

Petrini, O. 1991. Fungal endophytes of tree leaves. Pages 179-197 in : J.H. Andrews and S.S. Hirano (eds.), Microbial ecology of leaves, Springer-Verlag, New York.

QSPP. 1992. Names of plant diseases in Canada. Quebec Society for the Protection of Plants, Quebec. 477 pp.

Ross, R.G. 1953. The microflora of apple leaves and its relationship to Venturia inaequalis (Cke) Wint. M.Sc. Thesis, McGill University, Montreal, Canada. 102 pp.

Simard J., R.L. Pelletier, and J.G. Coulson. 1957. Screening of microorganisms inhabiting apple leaf for their antibiotic properties against Venturia inaequalis (Cke) Wint. Annual Report of the Quebec Society for the Protection of Plants 39 : 59-67. 